\title{
In Vitro Protection by Crataegus microphylla Extracts Against Oxidative Damage and Enzyme Inhibition Effects
}

\author{
Crataegus microphylla Ekstrelerinin Oksidatif Hasara Karşı In Vitro Koruma \\ ve Enzim İnhibisyonu Etkileri
}

\author{
(D) Gülin RENDA', (D) Arzu ÖZEL 2*, (D) Burak BARUT², (DBüşra KORKMAZ', (D) Nurettin YAYLI’ \\ ${ }^{1}$ Karadeniz Technical University, Faculty of Pharmacy, Department of Pharmacognosy, Trabzon, Turkey \\ ${ }^{2}$ Karadeniz Technical University, Faculty of Pharmacy, Department of Biochemistry, Trabzon, Turkey
}

\begin{abstract}
Objectives: Crataegus species have been used as food and also in folk medicine for the treatment of various diseases. The present study aimed to make investigations on the biologic properties of different extracts prepared from Crataegus microphylla C. Koch, which was collected from Turkey. Materials and Methods: Dried leaf, stem bark, and fresh fruit samples of $C$. microphylla were separated and ethanol extract, acidified $(0.5 \% \mathrm{HCl}$, $\mathrm{pH}:$ 2.5) ethanol extract, ethanol:water (1:1) extract, methanol extract, acidified $(0.5 \% \mathrm{HCl}, \mathrm{pH}: 2.5)$ methanol extract, methanol:water (1:1) extract, water extract, and acidified $(0.5 \% \mathrm{HCl}, \mathrm{pH}: 2.5)$ water extract were prepared for each. Various biologic effects such as the prevention of oxidative DNA damage, acetylcholinesterase, tyrosinase, $\alpha$-glucosidase inhibition, and antioxidant effects with 2,2-diphenyl-1-picrylhydrazyl (DPPH) radical scavenging, PRAP, and FRAP assays of these extracts at different concentrations were studied.

Results: Acidified methanol extract of stem barks exhibited the highest acetylcholinesterase and tyrosinase inhibitions among the other extracts with IC ${ }_{50}$ values of $204.02 \pm 0.95 \mu \mathrm{g} / \mathrm{mL}$ and $37.30 \pm 0.27 \mu \mathrm{g} / \mathrm{mL}$, respectively. Acidified ethanol extract of leaves was the most efficient extract against $\alpha$-glucosidase, giving an $\mathrm{IC}_{50}$ of $15.78 \pm 0.14 \mu \mathrm{g} / \mathrm{mL}$. The $\mathrm{IC}_{50}$ value of the acidified ethanol extract for DPPH was $9.89 \pm 0.09 \mu \mathrm{g} / \mathrm{mL}$. Methanol extracts of leaves and stem barks at the dose of $125 \mu \mathrm{g} / \mathrm{mL}$ exhibited significant protective activity against DNA strand scission by hydroxyl radicals (.OH) on supercoiled pBR322 DNA.
\end{abstract}

Conclusion: Acidified methanol or ethanol extracts prepared with stem bark and leaf from C. microphylla have potential antioxidant, hypoglycemic, and neuroprotective effects.

Key words: DPPH, FRAP, hawthorn, PRAP, Rosaceae

öz

Amaç: Crataegus türleri gıda olarak ve halk arasında çeşitli hastalıkların tedavisinde kullanılmaktadır. Bu çalıșma Türkiye'den toplanan Crataegus microphylla C. Koch'tan hazırlanan farklı ekstraktların biyolojik özelliklerini araştırmayı amaçlamaktadır.

Gereç ve Yöntemler: Kurutulmuş yaprak, gövde kabuğu ve taze meyve örnekleri ayrıldı ve etanol ekstresi, asitlendirilmiş (\%0.5 HCl, pH: 2.5 ) etanol ekstresi, etanol:su (1:1) ekstresi, metanol ekstresi, asitlendirilmiş (\%0.5 HCl, pH: 2.5) metanol ekstresi, metanol:su (1:1) ekstresi, su ekstresi ve asitlendirilmiş (\%0.5 HCl, pH: 2.5) su ekstresi hazırlandı. Ekstrelerin oksidatif DNA hasarının önlenmesi, asetilkolinesteraz, tirozinaz, $\alpha$-glukozidaz inhibisyonu ve antioksidan aktivitesi 2,2-difenil-1-pikrilhidrazil (DPPH) radikal süpürme, PRAP ve FRAP gibi çeşitli biyolojik aktiviteleri farklı konsantrasyonlarda araştırılmıştır.

Bulgular: Gövde kabuklarından asitlendirilmiş metanol ekstraktı sırasıyla $204.02 \pm 0.95 \mu \mathrm{g} / \mathrm{mL}$ ve $37.30 \pm 0.27 \mu \mathrm{g} / \mathrm{mL} I_{50}$ değerleri ile diğer esktreler arasında en yüksek asetilkolinesteraz ve tirozinaz inhibisyonu göstermiştir. Yaprakların asitlendirilmiş etanol ekstresi, $\alpha$-glukosidaz enzimine karşı $15.78 \pm 0.14 \mathrm{\mu g} / \mathrm{mL}$ ile en düşük $I_{50}$ değerini göstermiştir. DPPH için asitleştirilmiş etanol ekstraktının $\mathrm{IC}_{50}$ değeri $9.89 \pm 0.09 \mathrm{ug} / \mathrm{mL}$ bulunmuştur. $125 \mu \mathrm{g} / \mathrm{mL}$ dozunda yaprakların ve gövde kabuklarının metanol ekstreleri, süpersarmal pBR322 DNA üzerinde hidroksil iyonu ( $\mathrm{OH}$ ) tarafından DNA sarmalının kesilmesine karşı önemli koruma aktivitesi sergiledi.

Sonuç: C. microphylla gövde kabuğu ve yaprak ile hazırlanan asitlendirilmiş metanol veya etanol ekstrelerinin potansiyel antioksidan, hipoglisemik ve nöroprotektif etkileri bulunmaktadır.

Anahtar kelimeler: DPPH, FRAP, alıç, PRAP, Rosaceae

*Correspondence: E-mail: arzuozenozel@ktu.edu.tr, Phone: +90 4623778803 ORCID-ID: orcid.org/0000-0001-7381-5575

Received: 03.03.2017, Accepted: 11.05.2017

-Turk J Pharm Sci, Published by Galenos Publishing House. 


\section{INTRODUCTION}

The Crataegus genus (Rosaceae) has approximately 200 species worldwide and 24 species in Turkey.,2 All plant species in this genus have the common name "Hawthorn". ${ }^{3}$ Crataegus microphylla $\mathrm{C}$. Koch is one of the wild edible fruits in Turkey. ${ }^{4}$ Crataegus species have been used as food and also in folk medicine for the treatment of different heart diseases and diabetes for hundreds of years. ${ }^{3,5,6}$ Fruits of the Crataegus species are used for stimulating digestion, improving blood circulation, and for the treatment of diarrhea, abdominal pain, amenorrhea, hypertension, and hyperlipidemia in Chinese traditional medicine. ${ }^{3}$ In addition, products that include the extracts of some Crataegus species are consumed as natural health products in Europe, Asia, and North America. ${ }^{7,8}$ Epidemiologic studies and associated meta-analyses showed that long-term consumption of plant polyphenols in diet protected against the development of cancers, cardiovascular diseases, diabetes, osteoporosis, and neurodegenerative diseases. ${ }^{9-13}$

In addition to its ethnopharmacologic use, the preventive effect of C. microphylla fruit extract against genotoxicity induced by methyl methanesulfonate has been investigated in human cultured blood lymphocytes and found to reduce the oxidative stress and genotoxicity induced by toxic compounds. This activity is attributed to its phenolic content and antioxidant potential. ${ }^{14}$

By the results of many pharmacologic studies performed with extracts and isolated constituents of Crataegus species, flavonoids and proantocyanidins were found to be responsible for the cardiovascular protective activity of the plant. ${ }^{8}$ With phytochemical studies, D-sorbitol, apigenin, naringenin, eriodictoyl, vitexin, vitexin-4'-O-rhamnoside, hesperetin, luteolin, luteolin 7-O-glucoside, quercetin, and hyperoside have been isolated from C. microphylla. ${ }^{15-18}$ Hyperoside was found to be the major compound in leaves and flowers of C. microphylla. ${ }^{17}$

Oxidative stress is involved in several neurodegenerative disease and degenerative disorders such as cancer, arteriosclerosis, and diabetes. ${ }^{19}$ As the accepted consent, the phenolic content determines the antioxidative properties of plant species, and polyphenols play a role in the prevention of chronic human diseases. ${ }^{9}$ The prevention of DNA damage, antioxidant activity, and total phenolic and flavonoid contents of extracts of new sources are very important in explaining their biochemical properties and behavior. In particular, studies of inhibition of these enzymes and prevention of DNA oxidative damage will also enlighten researchers to perform further studies in terms of neurodegenerative enzyme inhibition, anti-diabetic activity, and preventing the conversion to mutagenic forms with various extracts from C. microphylla.

In this study, prevention of oxidative DNA damage, acetylcholinesterase (AChE), tyrosinase, $\alpha$-glucosidase inhibition behaviours and antioxidant effects: 2,2-diphenyl1-picrylhydrazyl (DPPH) radical scavenging effect, phosphomolybdenum-reducing antioxidant power (PRAP), ferric-reducing antioxidant power (FRAP) with total phenolic and total flavonoid contents of the C. microphylla leaves, stem barks and fruits that were extracted with ethanol, methanol, and water were investigated. The biologic evaluation of the aerial part extracts of C. microphylla was investigated for the first time in this work.

\section{EXPERIMENTAL}

\section{Plant material and sample preparation}

Leaf, stem bark (B), and fruit of C. microphylla were collected from Kale, Gümüşhane-Turkey, in September 2015. A voucher specimen was deposited at the Hacettepe University, Faculty of Pharmacy, Herbarium (Voucher No: HUEF 15021).

Dried leaf ( $L$ ), $B$ and fresh fruit $(F)$ samples of $C$. microphylla were separated and $50 \mathrm{~g}$ of $\mathrm{L}, \mathrm{B}$, and $\mathrm{F}$ was extracted with 250 $\mathrm{mL}$ of various solvents to obtain ethanol extract (1), acidified $(0.5 \% \mathrm{HCl}, \mathrm{pH}: 2.5)$ ethanol extract (2), ethanol:water (1:1) extract (3), methanol extract (4), acidified $(0.5 \% \mathrm{HCl}, \mathrm{pH}: 2.5)$ methanol extract (5), methanol:water (1:1) extract (6), water extract (7), and acidified $(0.5 \% \mathrm{HCl}, \mathrm{pH}$ : 2.5) water extract (8) for each, respectively. Extractions were performed in a shaker for $4 \mathrm{~h} \times 3$ times, for each sample. Extracts were filtered and evaporated under reduced pressure using a rotary evaporator. Crude extracts were kept in a refrigerator at $+4^{\circ} \mathrm{C}$ until used. All of the extracts in Table 1 were tested in all assays.

Table 1. The codes and yields (w/w) of the extracts prepared with various solvents of leaf, bark and fruit from C. microphylla

\begin{tabular}{|c|c|c|}
\hline & Codes & Yields (w/w) \\
\hline Leaf in $\mathrm{EtOH}$ & L1 & 16.2 \\
\hline Leaf in $\mathrm{EtOH}, \mathrm{pH} 2.5$ & L2 & 15.8 \\
\hline Leaf in $\mathrm{EtOH}: \mathrm{H}_{2} \mathrm{O}(1: 1)$ & L3 & 23.2 \\
\hline Leaf in $\mathrm{MeOH}$ & L4 & 20.6 \\
\hline Leaf in $\mathrm{MeOH}, \mathrm{pH} 2.5$ & L5 & 17.6 \\
\hline Leaf in $\mathrm{MeOH}: \mathrm{H}_{2} \mathrm{O}(1: 1)$ & L6 & 24.6 \\
\hline Leaf in $\mathrm{H}_{2} \mathrm{O}$ & $\mathrm{L} 7$ & 10.2 \\
\hline Leaf in $\mathrm{H}_{2} \mathrm{O}, \mathrm{pH} 2.5$ & L8 & 18.2 \\
\hline Bark in $\mathrm{EtOH}$ & B1 & 5.8 \\
\hline Bark in EtOH, pH 2.5 & B2 & 7.4 \\
\hline Bark in EtOH: $\mathrm{H}_{2} \mathrm{O}(1: 1)$ & B3 & 9.1 \\
\hline Bark in $\mathrm{MeOH}$ & B4 & 10.0 \\
\hline Bark in $\mathrm{MeOH}, \mathrm{pH} 2.5$ & B5 & 8.3 \\
\hline Bark in $\mathrm{MeOH}: \mathrm{H}_{2} \mathrm{O}(1: 1)$ & B6 & 9.6 \\
\hline Bark in $\mathrm{H}_{2} \mathrm{O}$ & B7 & 7.3 \\
\hline Bark in $\mathrm{H}_{2} \mathrm{O}, \mathrm{pH} 2.5$ & $\mathrm{B8}$ & 6.8 \\
\hline Fruit in $\mathrm{EtOH}$ & $\mathrm{F} 1$ & 10.9 \\
\hline Fruit in $\mathrm{EtOH}, \mathrm{pH} 2.5$ & $\mathrm{~F} 2$ & 10.0 \\
\hline Fruit in $\mathrm{EtOH}: \mathrm{H}_{2} \mathrm{O}(1: 1)$ & F3 & 6.3 \\
\hline Fruit in $\mathrm{MeOH}$ & $\mathrm{F} 4$ & 10.7 \\
\hline Fruit in $\mathrm{MeOH}, \mathrm{pH} 2.5$ & F5 & 9.8 \\
\hline Fruit in $\mathrm{MeOH}: \mathrm{H}_{2} \mathrm{O}(1: 1)$ & F6 & 5.7 \\
\hline Fruit in $\mathrm{H}_{2} \mathrm{O}$ & $\mathrm{F} 7$ & 8.6 \\
\hline Fruit in $\mathrm{H}_{2} \mathrm{O}, \mathrm{pH} 2.5$ & F8 & 9.5 \\
\hline
\end{tabular}

*L: Leaf, B: Bark, F: Fruit, w/w: Weight per weight 


\section{Enzyme inhibitions}

\section{Acetylcholinesterase inhibition}

AChE inhibition was examined using the method described by Ellman et al. ${ }^{20}$ and Ingkaninan et al. ${ }^{21}$ Galantamine was used as the positive control. All extracts (L1-8, B1-8 and F1-8) at various concentrations were separately added to a 96-well microplate and incubated for $15 \mathrm{~min}$ at $25^{\circ} \mathrm{C}$. Absorbance was measured at $412 \mathrm{~nm}$ using a 96-well microplate reader. Inhibition of AChE was calculated using Formula 1 , in which $A_{\text {control }}$ is the activity of enzyme without extract (solvent in buffer $\mathrm{pH}=8$ ) and $\mathrm{A}_{\text {sample }}$ is the activity of enzyme with extract at various concentrations. The inhibitory concentrations of $50 \%$ of $\mathrm{AChE}\left(\mathrm{IC}_{50}\right)$ values were calculated from the graph of the percentage inhibition against extract concentrations.

Formula 1. Inhibition (\%) $=\left[\frac{\text { Asample Acontrol }}{\text { Acontrol }}\right] \times 100$

\section{Tyrosinase inhibition}

Tyrosinase inhibition was examined using the method described by Masuda et al. ${ }^{22}$ Kojic acid was used as the positive control. The tyrosinase inhibition percentage of all extracts (L1-8, B1-8 and F1-8) $(20 \mu \mathrm{L})$ at various concentrations was calculated using Formula 1. The inhibitory concentration of $50 \%$ of tyrosinase $\left(\mathrm{IC}_{50}\right)$ values was calculated from the graph of the percentage inhibition against extract concentrations.

\section{$\alpha$-glucosidase inhibition}

$\alpha$-glucosidase inhibition was examined using the method described by da Silva Pinto et al. ${ }^{23}$ Acarbose was used as the reference drug. The $\alpha$-glucosidase inhibition percentage of all extracts (L1-8, B1-8 and F1-8) at various concentrations was calculated using Formula 1. The inhibitory concentration of $50 \%$ of $\alpha$-glucosidase $\left(\mathrm{IC}_{50}\right)$ values was calculated from the graph of the percentage inhibition against extract concentrations.

\section{Antioxidant activities}

\section{Determination of total phenolic contents}

The Folin-Ciocalteu reagent was used to determine the total phenolic content according to the method described by Kähkönen et al. ${ }^{24}$ Gallic acid was also used as standard compound. The total phenolic contents of all extracts (L1-8, B1-8 and F1-8) were expressed as $\mathrm{mg}$ gallic acid equivalents (GAE) per $g$ of dry weight sample.

\section{Determination of total flavonoid contents}

The total flavonoid content was measured by using the aluminum nitrate assay (Chang et al. ${ }^{25}$ 2002). Quercetin was used as the standard compound. The total flavonoid contents of all extracts (L1-8, B1-8 and F1-8) were expressed as mg quercetin equivalents ( $Q E)$ per $g$ of dry weight sample.

\section{$D P P H$ radical scavenging assay}

The DPPH radical scavenging activities of all extracts (L1-8, B1-8 and F1-8) were examined using the method described by Blois compared with gallic acid and ascorbic acid as the reference compounds. ${ }^{26}$ The absorbance of the sample $\left(\mathrm{A}_{\text {sample }}\right)$ was measured at $517 \mathrm{~nm}$. An assay mixture without samples was used as a control $\left(A_{\text {control }}\right)$. The inhibition percentage was calculated using Formula 2. The scavenging concentrations of $50 \%$ of DPPH $\left(\mathrm{SC}_{50}\right)$ values were calculated from the graph of the percentage inhibition against extract concentrations.

Formula 2.

Scavenging effects $(\%)=\left[\frac{\left(A_{\text {control }}-A_{\text {sample }}\right)}{\left(A_{\text {control }}\right)}\right] \times 100$

PRAP assay

PRAP of all L1-8, B1-8 and F1-8 extracts were examined using phosphomolybdic acid. ${ }^{27}$ The PRAP of extracts was expressed as $\mathrm{mg} \mathrm{QE}$ per $\mathrm{g}$ of dry weight sample.

\section{FRAP assay}

FRAP of all L1-8, B1-8 and F1-8 extracts was examined using the method described by Oyaizu. ${ }^{28}$ The ferric-reducing power of extracts was expressed as butylated hdroxyanisole equivalents (BHAE) per g of dry weight sample.

\section{Prevention of DNA oxidative damage}

The protective effects of all L1-8, B1-8 and F1-8 extracts of $C$. microphylla against DNA oxidative damage induced by hydroxyl radical were monitored by the conversion of pBR322 to open circular form according to Yeung et al. ${ }^{29}$ Total volume of reaction mixture $(10 \mu \mathrm{L})$ contained Tris- $\mathrm{HCl}$ buffer $(\mathrm{pH} 7.0)$, supercoiled plasmid pBR322 DNA (250 ng), $1 \mathrm{mM} \mathrm{FeSO}_{4}, 2 \% \mathrm{H}_{2} \mathrm{O}_{2}$ and 125 $\mu \mathrm{g} / \mathrm{mL}$ of extracts. The mixtures were incubated at $37^{\circ} \mathrm{C}$ for 1 h. The reaction was stopped by adding $5 \mu \mathrm{L}$ of loading buffer (0.2\% bromophenol blue, $4.5 \%$ sodium dodecyl sulfate, $0.2 \%$ xylene cyanol, $30 \%$ glycerol). The mixtures were then loaded on $0.8 \%$ agarose gel containing EB $1 \mathrm{mg} / \mathrm{mL}$ in TAE (Tris-acetateEDTA). Electrophoresis was carried out at $100 \mathrm{~V}$ for $90 \mathrm{~min}$. and the resulting image was visualized with BioRad Gel Doc XR system.

\section{Statistical analysis}

The experiments were performed in triplicate and the results are expressed as the mean \pm standard deviation. The statistical analysis was performed with SPSS 15.0 for Windows and Microsoft Excel for Windows 10. The differences between the extracts were evaluated using one-way analysis of variance flowed by Duncan's multiple range tests. $P<0.05$ was considered statistically significant.

\section{RESULTS}

\section{Enzyme inhibition}

AChE inhibition results of extracts of leaf, stem bark and fruit from C. microphylla are presented in Table 2. All of the extracts had low AChE inhibition values when compared with galanthamine with $I C_{50}$ values of $7.34 \pm 0.09 \mu \mathrm{g} / \mathrm{mL}$. However, among the tested extracts, B5 and B2 exhibited the highest $\mathrm{AChE}$ inhibitions with $I_{50}$ values of $204.02 \pm 0.95 \mu \mathrm{g} / \mathrm{mL}$ and $230.58 \pm 3.18 \mu \mathrm{g} / \mathrm{mL}$, respectively. Some of the extracts (L8, B3, B7, F1, F3, F4, F6, F7 and F8) were inactive against AChE enzyme. 
The results of the tyrosinase enzyme inhibitory effect of the extracts are given in Table 2 . The lowest $I_{50}$ values of the extracts indicate a higher inhibition effectiveness. All of the extracts from $C$. microphylla exhibited promising activity against tyrosinase compared with kojic acid. Methanol and ethanol extracts of stem bark of C. microphylla displayed remarkable tyrosinase inhibitory activities with $I_{50}$ values of lower than $50 \mu \mathrm{g} / \mathrm{mL}$. The B2 extract exhibited the highest tyrosinase inhibition with $\mathrm{IC}_{50}$ values of $37.30 \pm 0.27 \mu \mathrm{g} / \mathrm{mL}$ ( $\left.p<0.05\right)$, and B5 inhibited tyrosinase with $\mathrm{IC}_{50}$ values of $37.41 \pm 0.17 \mu \mathrm{g} / \mathrm{mL}$.

In this work, $I C_{50}$ values of $\alpha$-glucosidase inhibition of $C$. microphylla extracts are presented in Table 2. A lower $I C_{50}$

\begin{tabular}{|c|c|c|c|}
\hline Samples* & AChE & Tyrosinase & $\alpha$-glucosidase \\
\hline L1 & $349.14 \pm 1.34^{a}$ & $59.19 \pm 0.14$ & $90.35 \pm 1.32$ \\
\hline L2 & $472.81 \pm 3.77$ & $51.30 \pm 0.26$ & b15.78 \pm 0.14 \\
\hline L3 & $355.83 \pm 1.84$ & $70.71 \pm 0.16$ & $258.13 \pm 2.41$ \\
\hline L4 & $932.83 \pm 2.31$ & $49.31 \pm 0.13$ & $191.36 \pm 1.92$ \\
\hline L5 & $382.20 \pm 2.84$ & $43.74 \pm 0.28$ & b29.92 0.26 \\
\hline L6 & $324.77 \pm 1.72$ & $52.42 \pm 0.73$ & $57.80 \pm 0.94$ \\
\hline $\mathrm{L} 7$ & $513.35 \pm 2.37$ & $145.80 \pm 0.51$ & $167.94 \pm 1.36$ \\
\hline L8 & nd & $142.42 \pm 1.42$ & $270.64 \pm 2.42$ \\
\hline B1 & $314.83 \pm 2.50$ & $38.79 \pm 0.82$ & $465.60 \pm 2.26$ \\
\hline $\mathrm{B} 2$ & $230.58 \pm 3.18$ & ь $37.41 \pm 0.17$ & b38.25 \pm 0.51 \\
\hline B3 & nd & $41.52 \pm 0.35$ & $164.95 \pm 1.32$ \\
\hline B4 & $538.31 \pm 1.52$ & $38.25 \pm 0.62$ & $367.65 \pm 2.42$ \\
\hline B5 & $204.02 \pm 0.95$ & ь $37.30 \pm 0.27$ & b39.63 \pm 0.62 \\
\hline B6 & $630.21 \pm 2.52$ & $40.32 \pm 0.21$ & $68.31 \pm 0.22$ \\
\hline B7 & nd & $155.90 \pm 1.47$ & $256.76 \pm 2.35$ \\
\hline B8 & $298.41 \pm 1.36$ & $144.47 \pm 0.31$ & b46.02 \pm 0.52 \\
\hline $\mathrm{F} 1$ & nd & $129.34 \pm 0.46$ & nd \\
\hline $\mathrm{F} 2$ & $301.77 \pm 2.25$ & $139.37 \pm 0.32$ & $624.22 \pm 2.48$ \\
\hline F3 & nd & $85.77 \pm 0.41$ & nd \\
\hline $\mathrm{F} 4$ & nd & $62.11 \pm 0.58$ & $465.12 \pm 3.42$ \\
\hline F5 & $434.53 \pm 3.27$ & $56.02 \pm 0.21$ & $250.94 \pm 1.95$ \\
\hline F6 & nd & $147.29 \pm 0.52$ & nd \\
\hline $\mathrm{F} 7$ & nd & $165.75 \pm 0.47$ & nd \\
\hline F8 & nd & $149.83 \pm 0.69$ & $731.81 \pm 3.26$ \\
\hline Galantamine & $7.34 \pm 0.09$ & - & - \\
\hline Kojic acid & - & $24.01 \pm 0.02$ & - \\
\hline Acarbose & - & - & $31.92 \pm 0.08$ \\
\hline
\end{tabular}

${ }^{*}$ L: Leaf, B: Bark, F: Fruit, aValues expressed are means $\pm S D,{ }^{b}(p<0.05)$, nd: Not detected, AChE: Acetylcholinesterase value indicates strong inhibitory activity. L2, L5, B2, B5 and B8 extracts exhibited significant ( $p<0.05) \alpha$-glucosidase inhibition as shown in Table 2. $\mathrm{IC}_{50}$ values of $\mathrm{L} 2, \mathrm{~L} 5, \mathrm{~B} 2, \mathrm{~B} 5$ and $\mathrm{B} 8$ extracts were found to $15.78 \pm 0.14,29.92 \pm 0.26,38.25 \pm 0.51,39.63 \pm 0.62$ and $46.02 \pm 0.52 \mu \mathrm{g} / \mathrm{mL}$, respectively. On the other hand, F1, F3, F6, and F7 extracts had no $\alpha$-glucosidase inhibition effects. All of the data of $\alpha$-glucosidase inhibition indicated that L2, L5, B2, B5, and B8 extracts of C. microphylla could be effective hypoglcemic agents.

\section{Antioxidant activities}

The total phenolic contents of various extracts of $C$. microphylla leaves, stem barks, and fruits were determined from the gallic acid standard curve $\left(y=1.9251 x+0.3125, R^{2}=0.9967\right)$ and expressed as mg GAE/g dry weight. The total phenolic contents of $C$. microphylla stem barks and leaves were in the range of $13.22 \pm 0.38$ to $132.26 \pm 1.83 \mathrm{mg} \mathrm{GAE} / \mathrm{g}$ dry weight and $30.93 \pm 0.64$ to $85.26 \pm 1.60 \mathrm{mg} \mathrm{GAE} / \mathrm{g}$ dry weight, whereas extracts of fruits exhibited $5.00 \pm 0.18$ to $57.28 \pm 1.35 \mathrm{mg} \mathrm{GAE} / \mathrm{g}$ dry weight as shown in Figure 1. B1 $(123.11 \pm 2.38), B 2(132.26 \pm 1.83), B 4$ (111.84 \pm 2.19$)$, B5 $(120.40 \pm 2.89)$, and B6 (112.46 \pm 2.13$)$ extracts contained more than $100 \mathrm{mg} \mathrm{GAE} / \mathrm{g}$ dry weight. On the other hand, B7 and F8 extracts exhibited the lowest total phenolic contents $(13.22 \pm 0.38,5.00 \pm 0.18$ and $14.89 \pm 0.73 \mathrm{mg} \mathrm{GAE} / \mathrm{g}$ dry weight).

Total flavonoid contents of leaf, stem bark, and fruit extracts from C. microphylla were determined from the quercetin standard curve $\left(y=12.632 x \pm 0.509, R^{2}=0.9981\right)$ as shown in Figure 2 . The total flavonoid contents expressed as $\mathrm{mg} \mathrm{QE} / \mathrm{g}$ dry weight found in our extracts ranged from $0.97 \pm 0.09$ to $63.34 \pm 0.92 \mathrm{mg}$ QE/g dry weight. Total flavonoid contents of leaf extract from C. microphylla appeared higher than other extracts. The highest total flavonoid content was found in the L1 (63.34 $\pm 0.92 \mathrm{mg} \mathrm{QE} / \mathrm{g}$ dry weight) extract, followed by the $L 2(56.25 \pm 0.73 \mathrm{mg}$ QE/g dry

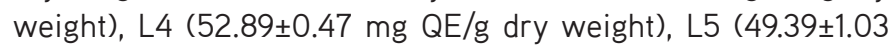
mg QE/g dry weight), and L6 ( $50.53 \pm 0.92 \mathrm{mg} \mathrm{QE} / \mathrm{g}$ dry weight) extracts. Stem bark extracts of $C$. microphylla were in the range of $0.97 \pm 0.09$ to $4.78 \pm 0.24 \mathrm{mg} Q \mathrm{QE} / \mathrm{g}$ dry weight.

Among the tested extracts, B2 $(9.89 \pm 0.09 \mu \mathrm{g} / \mathrm{mL}), \mathrm{B} 5(10.47 \pm 0.29$ $\mu \mathrm{g} / \mathrm{mL}), B 1(11.94 \pm 0.07 \mu \mathrm{g} / \mathrm{mL})$ and L2 $(12.29 \pm 0.07 \mu \mathrm{g} / \mathrm{mL})$

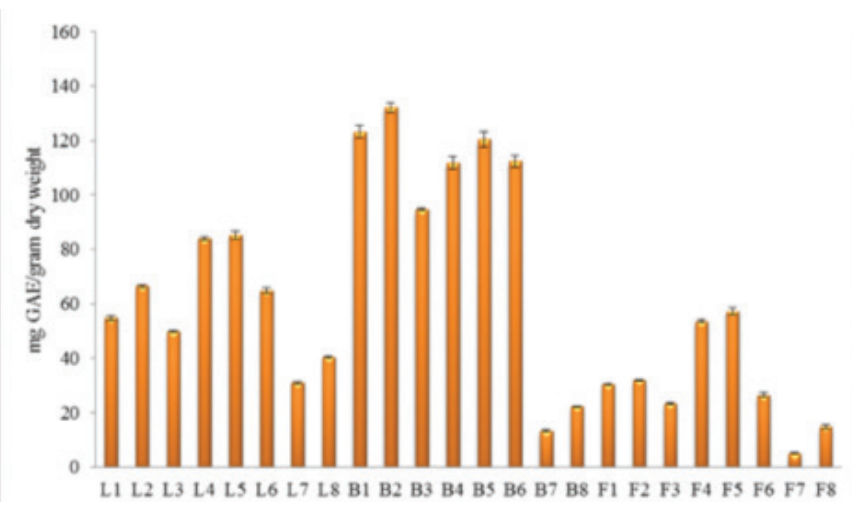

Figure 1. Total phenolic contents of the extracts

*L: Leaf, B: Bark, F: Fruit 


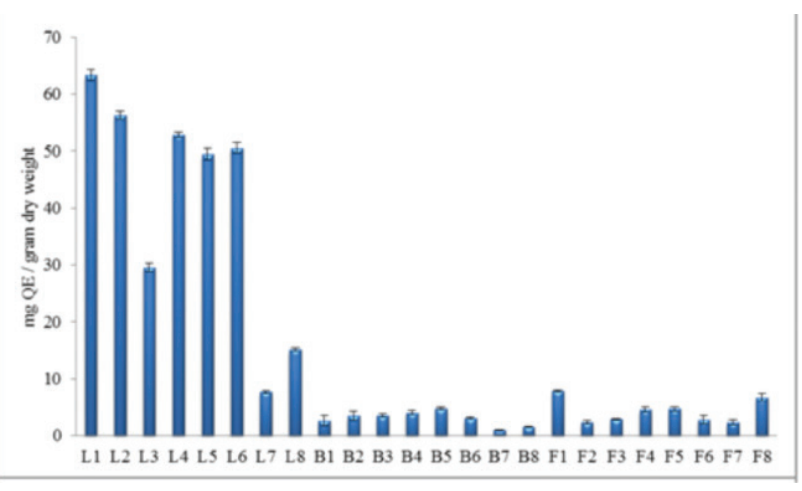

Figure 2. Total flavonoid contents of the extracts

*L: Leaf, B: Bark, F: Fruit
( $p<0.05$ ) extracts showed the highest scavenging activity in this assay as shown in Table 3 . The $\mathrm{IC}_{50}$ values of ethanol, acidified ethanol, methanol, and acidified methanol extracts of leaf and stem bark of $C$. microphylla were found lower than $70 \mu \mathrm{g} / \mathrm{mL}$. In the leaf, stem bark, and fruit extracts of C. microphylla, F7 extract showed the lowest DPPH radical scavenging activities. F5 extract exhibited the highest scavenging activities among the leaf extracts with $123.50 \pm 1.31 \mu \mathrm{g} / \mathrm{mL}$.

PRAP of leaf, stem bark, and fruit extracts from C. microphylla were determined from the quercetin standard curve $\left(y=0.0066 x \pm 0.5295, R^{2}=0.9986\right)$ as shown in Table 3. B2, B5, and B4 extracts displayed the highest reducing activities with $368.37 \pm 2.41,324.69 \pm 3.69$ and $247.75 \pm 2.73 \mathrm{mg} \mathrm{QE} / \mathrm{g}$ dry weight,

Table 3. DPPH radical scavenging, phosphomolybdenum-reducing antioxidant power (PRAP) and ferric-reducing antioxidant power (FRAP) assay values of leaf, bark, and fruit extracts from $C$. microphylla

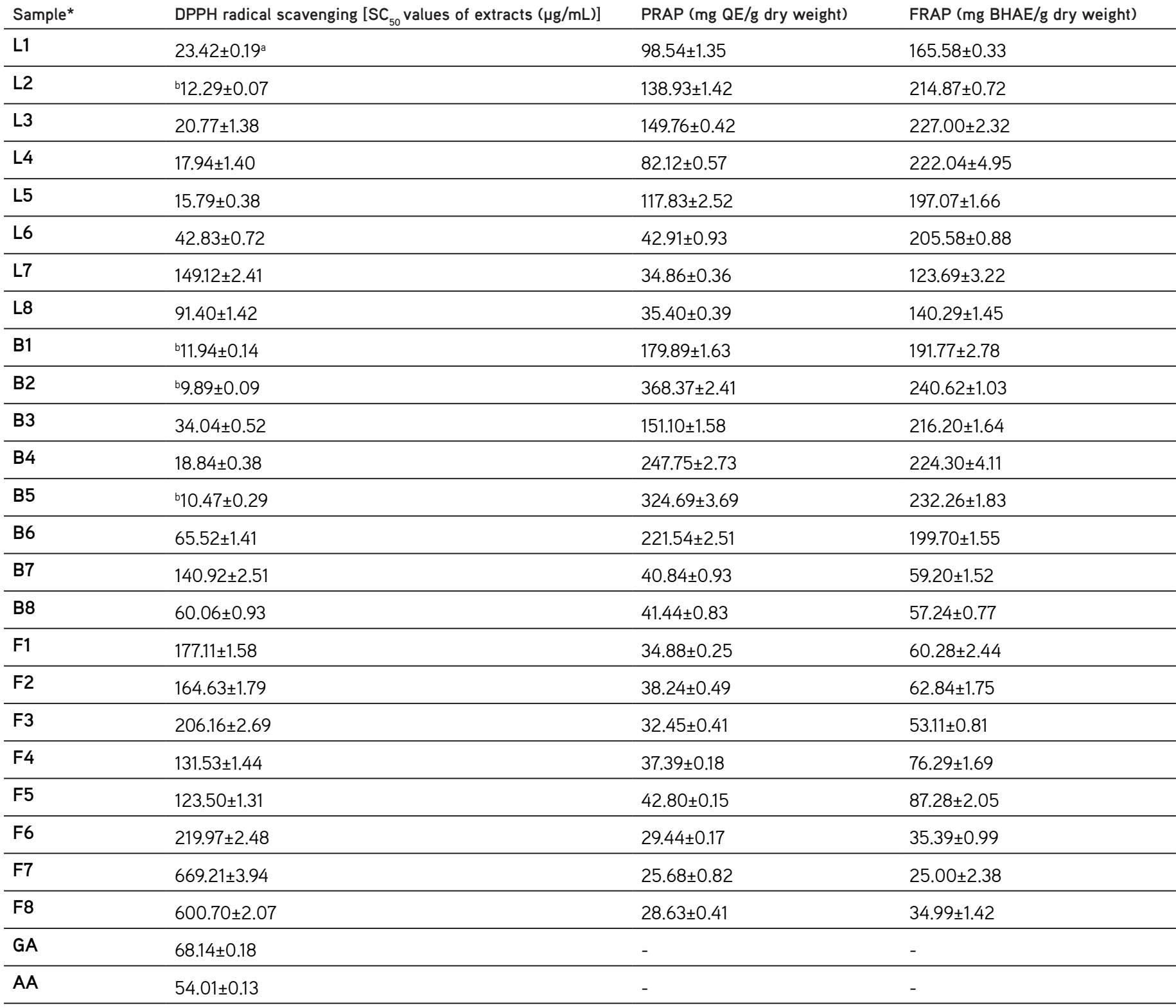

*L: Leaf, B: Bark, F: Fruit, aValues expressed are means \pm SD, b(p<0.05), BHAE: Butylated hdroxyanisole equivalents, QE: Quercetin equivalents, DPPH: 2,2-diphenyl-1picrylhydrazyl 
respectively; $F 7$ extract indicated the lowest activity $25.68 \pm 0.82$ $\mathrm{mg} Q \mathrm{E} / \mathrm{g}$ dry weight dry weight.

The results of the ability to reduce $\mathrm{Fe}^{3+}$ to $\mathrm{Fe}^{2+}$ are presented in Table 3. Stem bark and leaf extracts have a strong ferric reducing power. $\mathrm{B} 2$ and $\mathrm{B} 5$ extracts demonstrated the highest ferric reducing activity with $240.62 \pm 1.03 \mathrm{mg} B H A E / g$ dry weight and $232.26 \pm 1.83 \mathrm{mg} \mathrm{BHAE} / \mathrm{g}$ dry weight, respectively; F7 extract exhibited the lowest activity $25.00 \pm 2.38 \mathrm{mg} \mathrm{BHAE} / \mathrm{g}$ dry weight.

\section{Prevention of DNA oxidative damage}

It is known that when circular plasmid DNA is subjected to electrophoresis, the fastest to migrate is the supercoiled Form I, the slowest moving is the open circular Form II, and the linear Form III runs in between the other two forms. ${ }^{30}$ Prevention of DNA oxidative damage by $C$. microphylla is shown in Figure 3. The assay revealed that there was a formation of Form II and Form III because of hydroxyl radicals, as shown in Lane 2 on Figure 3.

However, with the addition of extracts, the conversion of supercoiled pBR322 DNA to open circular and linear forms decreased except with F8 extract at $125 \mu \mathrm{g} / \mathrm{mL}$. L4 and B4 extracts exhibited the highest preventative effect of DNA oxidative damage at $125 \mu \mathrm{g} / \mathrm{mL}$. The results proved that the prevention of DNA oxidative damage results were compatible with the radical scavenging assay.

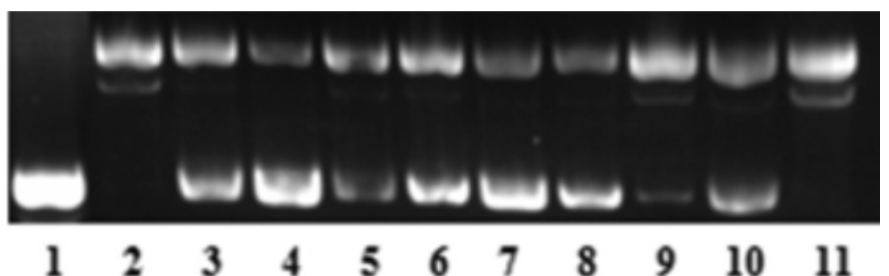

Figure 3. Protective effect of ethanol, methanol and water extracts of leaf, stem bark and fruit from C. microphylla in DNA oxidative damage assay. Lane 1: DNA control; Lane 2: DNA + $2 \% \mathrm{H}_{2} \mathrm{O}_{2}+1 \mathrm{mM} \mathrm{FeSO}_{4}$; Lane 3: DNA + $2 \%$ $\mathrm{H}_{2} \mathrm{O}_{2}+1 \mathrm{mM} \mathrm{FeSO}_{4}+\mathrm{L} 1$; Lane 4: DNA + 2\% $\mathrm{H}_{2} \mathrm{O}_{2}+1 \mathrm{mM} \mathrm{FeSO}_{4}+\mathrm{L}_{4}$; Lane 5: DNA + 2\% $\mathrm{H}_{2} \mathrm{O}_{2}+1 \mathrm{mM} \mathrm{FeSO}_{4}+\mathrm{L} 7$; Lane 6: DNA $+2 \% \mathrm{H}_{2} \mathrm{O}_{2}+1 \mathrm{mM} \mathrm{FeSO}_{4}+$ B1; Lane 7: DNA + 2\% $\mathrm{H}_{2} \mathrm{O}_{2}+1 \mathrm{mM} \mathrm{FeSO}_{4}+\mathrm{B} 4$; Lane 8: DNA + 2\% $\mathrm{H}_{2} \mathrm{O}_{2}+$ $1 \mathrm{mM} \mathrm{FeSO}_{4}+\mathrm{B7}$; Lane 9: DNA + 2\% $\mathrm{H}_{2} \mathrm{O}_{2}+1 \mathrm{mM} \mathrm{FeSO}_{4}+\mathrm{F} 1$; Lane 10: DNA $+2 \% \mathrm{H}_{2} \mathrm{O}_{2}+1 \mathrm{mM} \mathrm{FeSO}_{4}+\mathrm{F} 4$; Lane 11: DNA + 2\% $\mathrm{H}_{2} \mathrm{O}_{2}+1 \mathrm{mM} \mathrm{FeSO}_{4}+\mathrm{F} 7$. *L: Leaf, B: Bark, F: Fruit

\section{DISCUSSION}

Alzheimer's disease (AD) is one of the most frequent forms of dementia among older people. ${ }^{31}$ Although AChE inhibitors such as tacrine, donepezil, galantamine, and rivestigmine are important in the treatment for $A D$, they have adverse effects including gastrointestinal problems. ${ }^{32,33}$ Considering all the extracts, stem bark extracts, which had promising results at AChE inhibition, presented higher phenolic content than the other extracts (Figure 1). Recent studies have shown that antioxidants could scavenge oxygen radicals and could also attenuate inflammation pathways, and also pointed toward an association between $A D$ and inflammatory processes as well as antioxidant activity. ${ }^{34}$ From this point of view, it is stated that the use of antioxidants could be considered in the treatment of $A D .^{35}$

Parkinson's disease (PD) is one of the neurodegenerative diseases caused by dopaminergic neuron deficiency in the brain. ${ }^{36}$ Methanol and ethanol extracts from C. microphylla had higher inhibition activity than water extracts of $C$. microphylla due to total phenolic contents. There is a positive correlation between phenolic content and tyrosinase inhibition. ${ }^{37}$ These results showed that, extracts of C. microphylla, especially B5 extract, had promising neuroprotective potential due to AChE and tyrosinase inhibition.

$\alpha$-Glucosidase is a key enzyme in the hydrolysis of oligosaccharide and contributes to the formation of glucose..$^{38}$ It is important to find a new $\alpha$-glucosidase inhibitor for DM, such as natural products with low toxicity and adverse effects.

Organic solvents such as methanol and ethanol are known to be efficient for the extraction of phenolics. Besides, water is a good choice because it is used to make infusions and decoctions in herbal medicine. Also, acidified extraction systems were shown to be more efficient, especially for the hydrolysis of bound phenolic compounds. ${ }^{39,40}$ Due to the fact that many solvents may extract different compounds from plant tissues, we wanted to compare the results. The hydrolysation process was done with acidification and aglycones were obtained with acidified extracts (L2, 5, 8; B2, 5, 8; F2, 5, 8) (Table 1).

When we compared the extracts that were prepared with the same solvents, total phenolic contents of the acidified ones were found to be higher than the non-acidified ones (Figure 1). The total phenolic content of $L 2$ was found to be higher than $L 1$, L5 was higher than L4, and L8 was higher than L7. The same results were also obtained with $B$ and $F$ series (Figure 1).

Similar to our findings, it was reported that methanol extract of C. microphylla leaves indicated scavenging activity to $92.82 \pm 0.79 \%$ at $500 \mu \mathrm{g} / \mathrm{mL} .{ }^{41}$ According to Sharifi et al. ${ }^{42}, I_{50}$ values of methanol extract of C. microphylla were found as $13.01 \pm 0.2 \mu \mathrm{g} / \mathrm{mL}$.

The efficiency of an antioxidant extract was reported to be dependent on the $\mathrm{pH}$ of the solvents, as well as the solubility of antioxidant compounds by the solvents used for the extraction. ${ }^{43}$ Besides, methanol, ethanol, and water, which are commonly used solvents for extraction, and acidified alcohols are also widely used for extraction to release aglycone by chemical hydrolysis under acidic conditions. ${ }^{44}$ These results confirm that higher contents of total phenolic displayed higher DPPH free radical scavenging activities. All data showed that there was a relationship between the total phenolic and radical scavenging activities.

The results showed that methanol and ethanol extracts of leaf and bark from C. microphylla had more effective phosphomolybdenumreducing power than its water extractst. The B2 and B5 extracts with higher reducing power showed a positive correlation with phosphomolybdenum-reducing power assay.

Prevention of DNA oxidative damage was based on the ability of 
extracts (L1-8, B1-8 and F1-8) from C. microphylla to protect the supercoiled pBR322 DNA against damage caused by hydroxyl radicals $(\cdot \mathrm{OH})$. The antioxidant activity of $50 \%$ aqueous methanolic extract of whole plant of $C$. microphylla was studied before with an in vitro study and found to have moderate antioxidant activity. ${ }^{45}$ However, there are no previous works on the AChE, tyrosinase, $\alpha$-glucosidase inhibitory effects and oxidative DNA damage protective effects of various extracts of C. microphylla. In this context, it was aimed to compare the extractability of compounds that serve a function in the activity by various solvents.

\section{CONCLUSION}

This study presented the potential AChE, tyrosinase, $\alpha$-glucosidase inhibitory effects, total phenolic, total flavonoid contents, the antioxidant effects, and prevention of oxidative DNA damage of leaf, stem bark and fruit of various extracts (L1-8, B1-8 and F1-8) from C. microphylla. Concurrently, the correlation between the antioxidant activity and the DNA damage protective effects of the extracts (L1-8, B1-8 and F1-8) was described. Our results can be evaluated as a preliminary work for the use of $C$. microphylla extracts in herbal products.

Conflict of Interest: No conflict of interest was declared by the authors.

\section{REFERENCES}

1. Dönmez AA. The Genus Crataegus L. (Rosaceae) with special reference to hybridisation and biodiversity in Turkey. Turk J Bot. 2004;28:29-37.

2. Dönmez AA. A new species of Crataegus (Rosaceae) from Turkey. Bot J Linn Soc. 2005;148:245-249.

3. Chang $Q$, Zhong Z, Harrison F, Chow MS. Hawthorn. J Clin Pharmacol. 2002;42:605-612.

4. Browicz K. Crataegus L. In: PH Davis, ed. Flora of Turkey and the East Aegean Islands, Edinburgh University Press; Edinburgh; 1972;4:133-147.

5. Kumar D, Arya V, Bhat ZA, Khan NA, Prasad DN. The genus Crataegus: chemical and pharmacological perspectives. Rev Bras Farmacogn. 2012;22:1187-1200.

6. Rastogi S, Pandey MM, Rawat AK. Traditional herbs: a remedy for cardiovascular disorders. Phytomedicine. 2016;23:1082-1089.

7. Edwards JE, Brown PN, Talent N, Dickinson TA, Shipley PR. A review of the chemistry of the genus Crataegus. Phytochemistry. 2012;79:5-26.

8. Assessment report on Crataegus spp., folium cum flöre, European Medicines Agency Committee on Herbal Medicinal Products (HMPC), EMA/HMPC/159076/2014, Accessed on: 13 October 2014.

9. Pandey KB, Rizvi SI. Plant polyphenols as dietary antioxidants in human health and disease. Oxi Med Cell Longev. 2009;2:270-278.

10. Abidi E, Habib J, Yassine A, Chahine N, Mahjoub T, Ellak A. Effects of methanol extracts from roots, leaves, and fruits of the Lebanese strawberry tree (Arbutus andrachne) on cardiac function together with their antioxidant activity. Pharm Biol. 2016;54:1035-1041.

11. Graf BA, Milbury PE, Blumberg JB. Flavonols, flavones, flavanones, and human health: epidemiological evidence. J Med Food. 2005;8:281-290.

12. Arts IC, Hollman PC. Polyphenols and disease risk in epidemiologic studies. Am J Clin Nutr. 2005;81:317-325.
13. Palma-Duran SA, Vlassopoulos A, Lean M, Govan L, Combet E. Nutritional intervention and impact of polyphenol on glycohemoglobin ( $\mathrm{HbA1c}$ ) in non-diabetic and type 2 diabetic subjects: Systematic review and nmetaanalysis. Crit Rev Food Sci Nutr. 2017;57:975-986.

14. Hosseinimehr SJ, Azadbakht M, Tanha M, Mahmodzadeh A, Mohammadifar S. Protective effect of hawthorn extract against genotoxicity induced by methyl methanesulfonate in human lymphocytes. Toxicol Ind Health. 2011;27:363-369.

15. Strain HH. Sources of d-sorbitol. J Am Chem Soc. 1937;59:2264-2266.

16. Meriçli AH, Melikoğlu G. Investigations on Turkish Crataegus species. Acta Pharm Turcica. 2002;44:169-173.

17. Melikoğlu G, Bitiş L, Meriçli AH. Flavonoids of Crataegus microphylla. Nat Prod Res. 2004;18:211-213.

18. Tajali AA, Khazaeipool M. Effects of height and organs on flavonoids of Crataegus microphylla C. Koch in Iran Int J Biosci. 2012;2:54-58.

19. Moyo MS, Amoo O, Ncube B, Ndhlala AR, Finnie JF, Van Staden J. Phytochemical and antioxidant properties of unconventional leafy vegetables consumed in Southern Africa. S Afr J Bot. 2013;84:65-71.

20. Ellman GL, Courtney KD, Andres V Jr, Feather-stone RM. A new and rapid colorimetric determination acetylcholinesterase activity. Biochem Pharmacol. 1961;7:88-95.

21. Ingkaninan $\mathrm{K}$, de Best $\mathrm{CM}$, van der Heijden R, Hofte AJ, Karabatak B, Irth $\mathrm{H}$, Tjaden UR, van der Greef J, Verpoorte R. High-performance liquid chromatography with on-line coupled UV, mass spectrometric and biochemical detection for identification of acetylcholinesterase inhibitors from natural products. J Chromatogr A. 2000;872:61-73.

22. Masuda T, Yamashita D, Takeda Y, Yonemori S. Screening for tyrosinase inhibitors among extracts of seashore plants and identification of potent inhibitors from Garcinia subelliptica. Biosci Biotech Biochem. 2005;69:197-201.

23. da Silva Pinto M, Kwon YI, Apostolidis E, Lajolo FM, Genovese MI, Shetty K. Functionality of bioactive compounds in Brazilian strawberry (Fragaria x Ananassa Duch.) cultivars: evaluation of hyperglycemia and hypertension potential using in vitro models. J Agric Food Chem. 2008; $56: 4386-4392$.

24. Kähkönen MP, Hopia Al, Vuorela HJ, Rauha JP, Pihlaja K, Kujala TS, Heinonen M. Antioxidant Activity of Plant Extracts Containing Phenolic Compounds. J Agr Food Chem. 1999;47:3954-3962.

25. Chang CC, Yang MH, Wen MH, Wen HM, Chern JC. Estimation of total flavonoid content in propolis by two complementary colorimetric methods. J Food Drug Anal. 2002;10:178-182.

26. Blois MS. Antioxidant determinations by the use of a stable free radical. Nature. 1958;181:1199-1200.

27. Falcioni G, Fedeli D, Tiano L, Calzuola I, Mancinelli L, Marsili V, Gianfranceshi G. Antioxidant activity of wheat sprouts extract in vitro: inhibition of DNA oxidative damage. J Food Sci. 2002;67:2918-2922.

28. Oyaizu M. Studies on products of browning reactions-antioxidative activities of browning reaction prepared from glucosamine. Jpn J Nut. 1986;44:307-315.

29. Yeung SY, Lan WH, Huang CS, Lin CP, Chan CP, Chang MC, Jeng JH. Scavenging property of three cresol isomers against $\mathrm{H}_{2} \mathrm{O}_{2}$, hypochlorite, superoxide and hydroxyl radicals. Food Chem Toxicol. 2002;40:14031413.

30. Özel A, Barut B, Demirbaş Ü, Biyiklioglu Z. Investigation of DNA binding, DNA photocleavage, topoisomerase I inhibition and antioxidant activities of water soluble titanium(IV) phthalocyanine compounds. J Photochem Photobiol B. 2016;157:32-38. 
31. Lewis WG, Green LG, Grynszpan F, Radic Z, Carlier PR, Taylor P, Finn MG, Sharpless KB. Click chemistry in situ: acetylcholinesterase as a reaction vessel for the selective assembly of a femtomolar inhibitor from an array of building blocks. Angew Chem Int Engl. 2002;41:1053-1057.

32. Tian $T$, Weng $L$, Wang $S$, Weng $X$, Zhang $L$, Zhou X. Cationic tetrapyrrolic macromolecules as new acetylcholinesterase inhibitors. J Porphyr Phthalocyanines. 2009;13:893-902.

33. Zengin G, Nithiyanantham S, Locatelli M, Ceylan R, Uysal S, Aktumsek A, Kalai Selvi P, Maskovic P. Screening of in vitro antioxidant and enzyme inhibitory activities of different extracts from two uninvestigated wild plants: Centranthus longiflorus subsp. longiflorus and Cerinthe minor subsp. auriculata. Eur J Integr Med. 2016;8:286-292.

34. Ferreira A, Proença C, Serralheiro MLM, Araujo ME. The in vitro screening for acetylcholinesterase inhibition and antioxidant activity of medicinal plants from Portugal. J Ethnopharmacol. 2016;108:31-37.

35. Gibson GE, Huang HM. Oxidative stress in Alzheimer's disease. Neurobiol Aging. 2005;26:575-578.

36. Bao K, Dai Y, Zhu ZB, Tu FJ, Zhang WG, Yao XS. Design synthesis biphenyl derivatives mushroom tyrosinase inhibitors. Bioorg Med Chem. 2010;18:6708-6714.

37. Choi HK, Lim YS, Kim YS, Park YS, Lee CH, Hwang KW, Kwon DY. Freeradical-scavenging and tyrosinase-inhibition activities of Cheonggukjang samples fermented for various time. Food Chem. 2008;106:564-568.
38. Majouli K, Hlila MB, Hamdi A, Flamini G, Jannet HB, Kenani A. Antioxidant activity and $\alpha$-glucosidase inhibition by essential oils from Hertia cheirifolia (L). Ind Crop Prod. 2016;82:23-28.

39. Acosta-Estrada BA, Gutierrez-Uribe JA, Serna-Saldivar SO. Bound phenolics in foods, a review. Food Chem. 2014;152:46-55.

40. Mushtaq M, Sultana B, Anwar F, Batool S. Antimutagenic and antioxidant potential of aqueous and acidified methanol extracts from citrus limonum fruit residues. J Chil Chem Soc. 2015;60:2979-2983.

41. Artun FT, Karagöz A, Özcan G, Melikoğlu G, Anıl S, Kultur S, Sutlupinar N. In vitro evaluation of antioxidant activity of some plant methanol extracts. J BUON. 2016;21:720-725.

42. Sharifi N, Souri E, Ziai SA, Amin G, Amanlou M. Discovery of new angiotensin converting enzyme (ACE) inhibitors from medicinal plants to treat hypertension using an in vitro assay. DARU. 2013;21:74.

43. Kutlu T, Durmaz G, Ateș B, Yilmaz I, Çetin MȘ. Antioxidant properties of different extracts of black mulberry (Morus nigra L.). Turk $\mathrm{J}$ Biol. 2011;35:103-110.

44. Nollet LML, Toldra F. Handbook of Analysis of Active Compounds in Functional Foods, CRC Press; Boca Raton; 2012.

45. Serteser A, Kargioğlu M, Gök V, Bağci Y, Ozcan MM, Arslan D. Determination of antioxidant effects of some plant species wild growing in Turkey. Int J Food Sci Nutr. 2008;59:643-651. 